\title{
Particle breakdown and rumen digestion of fresh ryegrass (Lolium perenne L.) and lucerne (Medicago sativa L.) fed to cows during a restricted feeding period
}

\author{
BY G. C. WAGHORN ${ }^{1}$, I. D. SHELTON ${ }^{1}$ AND V. J. THOMAS \\ ${ }^{1}$ Biotechnology Division, and ${ }^{2}$ Applied Mathematics Division, DSIR, Private Bag, \\ Palmerston North, New Zealand
}

(Received 21 June 1988 - Accepted 14 October 1988)

1. Five rumen-fistulated cows were given freshly cut ryegrass (Lolium perenne L.) and lucerne (Medicago sativa L.), on separate occasions, to compare rates of particle breakdown and aspects of rumen fermentation.

2. Cattle were required to consume their daily allowance (offered ad $l i b$.) in two $2 \mathrm{~h}$ feeding periods daily.

3. During the first $2 \mathrm{~h}$ feeding period, dry matter (DM) intakes of ryegrass $(4.75 \mathrm{~kg})$ and lucerne $(4.85 \mathrm{~kg})$ were similar. Eating reduced $46 \%$ of ryegrass and $61 \%$ of lucerne to a size able to pass a $2 \mathrm{~mm}$ sieve $(P<0.001)$. Rumen DM particles retained on the 2 and $4 \mathrm{~mm}$ sieves had a low probability of passage out of the rumen, and accounted for only $6 \%$ of faecal DM with both feeds.

4. Ryegrass was cleared from the rumen more slowly than lucerne. During eating, rumen DM particles which could not pass the $2 \mathrm{~mm}$ sieve increased from 323 to $511 \mathrm{~g} / \mathrm{kg}$ for ryegrass and from 201 to $389 \mathrm{~g} / \mathrm{kg}$ for lucerne. The rate of particle size reduction for lucerne stem was similar to that for ryegrass.

5. When lucerne was eaten the increases in rumen volatile fatty acid (VFA) and ammonia concentrations were much greater than for ryegrass $(P<0.001)$. The proportions of plant chlorophyll released during eating were similar for both feeds $(0.570$ and 0.607$)$, but $2 \mathrm{~h}$ after eating $22.3 \mathrm{~g}$ had been released from lucerne (79.1\%) compared with $15.0 \mathrm{~g}$ from ryegrass $(63.8 \%)$. The flux of water from the rumen to the omasum was similar for ryegrass $(10.2$ litres $/ \mathrm{h})$ and lucerne $(12.7$ litres $/ \mathrm{h})$ during eating, but declined to 6.0 litres/h after eating with the lucerne diet.

Both ryegrass (Lolium perenne L.) and lucerne (Medicago sativa L.) are important forage species in New Zealand farming systems, yet they both have constraints which limit their usefulness. The lower productivity by sheep and cattle fed on ryegrass compared with legumes (e.g. Ulyatt, 1981) has been partly explained in sheep by the slower breakdown and clearance of ryegrass from the rumen (Ulyatt $e t$ al. 1986). With cattle the superior nutritive value of lucerne is lessened by frequent and often severe bloat (e.g. Clarke \& Reid, 1974; Howarth et al. 1986). The effectiveness of particle size reduction by cows fed on fresh ryegrass has not been reported, but rates of breakdown of ryegrass and lucerne, and consequent fermentative activity, may account in part for differences in nutritive value and the prevalence of bloat when cows are fed on fresh lucerne.

New Zealand dairy cows are usually rotationally grazed and given new pasture twice daily, after morning and afternoon milkings. Release to new pasture is associated with a rapid consumption of feed, and when bloat occurs it usually does so $1-2 \mathrm{~h}$ after cows begin eating.

The purpose of the present work was to investigate the relative rates of breakdown, digestion and outflow from the rumen, of particles from lucerne or ryegrass. This was done with a view to increasing the understanding of the possible factors involved in the process of rumen function which could be predisposing towards the condition of bloat.

In the present experiment a rapid consumption of feed was achieved by restricting feed availability to two $2 \mathrm{~h}$ periods per day. Variables measured were those which relate to nutritive value, i.e. rumen fill and particle size reduction, and those which have been implicated in the aetiology of bloat, i.e. degradation of plant leaf and release of chloroplasts (Howarth et al. 1982; Majak et al. 1985), fermentation (Clarke \& Reid, 1974), and volatile fatty acid (VFA) production (Sukachi \& Hoshino, 1981). 


\section{EXPERIMENTAL}

Five Friesian $\times$ Jersey cows aged 5-8 years, weighing $410-510 \mathrm{~kg}$ and fitted with rumen cannulas (Balch \& Cowie, 1962) were used in the present experiment. They were fed on a diet of freshly cut perennial ryegrass (cv. Grasslands Nui) for $30 \mathrm{~d}$, followed by a further $30 \mathrm{~d}$ when lucerne (cv. WL318) was given. The early commencement of growth by ryegrass compared with lucerne required a sequential feeding programme so that both feeds were given at a similar stage of maturity. Both feeds were lush, vegetative and approximately $300-500 \mathrm{~mm}$ high, and were harvested at 08.00 hours daily with a sickle-bar mower.

Cows were held indoors in stalls between 08.30 and 16.00 hours daily and released outside to sawdust pads overnight where only water and salt lick were available. Cows were fed ad lib. for two $2 \mathrm{~h}$ periods daily (09.30-11.30 hours and 13.30-15.30 hours). Feed intakes were recorded by weighing the bin with feed (Interface SSM 1000 load cell; Toledo Electronics Ltd) before eating and at $30 \mathrm{~min}$ intervals during the morning feeding period, and 60 min intervals during the afternoon feeding. Water was not available between 08.30 and 16.00 hours, as previous experience had shown that cows had no interest in drinking when offered green feeds under this feeding regimen.

All experimental procedures were undertaken during the final $10 \mathrm{~d}$ of each feeding period. Cows were given $10 \mathrm{ml}$ light paraffin oil before morning and afternoon feeding during the experimental period when lucerne was fed, to prevent bloat. Bloat often causes cows to reduce their feed intake. Bloat had occurred during the preliminary period of lucerne feeding.

\section{Rumen bailing and sampling procedures}

Rumen digesta were removed by bailing, then weighed, sampled and returned to each cow on each of $6 \mathrm{~d}$ during the experimental period at the following times of day (hours): 09.00 (prefeeding), 10.00, 10.30, 11.30, 13.30 ( $2 \mathrm{~h}$ after eating), and again at 09.00 . Two bailings were done at 09.00 hours because the prefeeding pool size formed the basis of most calculations. With one cow fed on lucerne the 09.00 hours bailing wet matter (WM) pools differed by more than $10 \%$ so that a third bailing was performed and a mean of the three values was used. Cows were bailed only once daily, and not more than $3 \mathrm{~d}$ in succession. Bailing took 10-25 min per cow, depending on rumen fill and was performed by one operator throughout. Bailing had no apparent effect on the cow's intake or comfort.

Bailed contents were thoroughly mixed in the vertical plane for about $1 \mathrm{~min}$, by tumbling the contents within the bailing drum using both hands. This procedure prevented the liquid phase of digesta settling in the bottom of the drum. Samples were taken by cupping both hands together and plunging deep into the mixed contents, scooping up about $300 \mathrm{~g} \mathrm{WM}$. This procedure had been shown previously to produce replicate samples of very similar dry matter (DM) and particle size distribution. In this experiment, when the difference between duplicate DM samples from each bailing was expressed as a proportion of the mean value, then for ryegrass the values for thirty bailings averaged 0.039 (SE 0.0047), i.e. the difference between duplicate DM samples was $3.9 \%$. Lucerne digesta were easier to subsample and the values for thirty bailings averaged 0.019 (SE 0.0034 ), i.e. the difference between duplicate DM samples was $1.9 \%$.

Samples were taken for determination of DM ( $300 \mathrm{~g}$ WM in duplicate), particle size distribution $(300 \mathrm{~g} \mathrm{WM})$, chlorophyll content of particulate material $(50 \mathrm{~g} \mathrm{WM}$ in duplicate), chromium and VFA concentration ( $25 \mathrm{ml}$ rumen fluid acidified with $4 \mathrm{ml} 5 \mathrm{M}$ sulphuric acid saturated with magnesium sulphate), and ammonia determination $(1 \mathrm{ml}$ rumen fluid into $9 \mathrm{ml} 10 \% \mathrm{H}_{2} \mathrm{SO}_{4}$ ). $\mathrm{pH}$ was determined by inserting the electrode into the bailed digesta. Digesta DM was determined by drying for $48 \mathrm{~h}$ at $95^{\circ}$. Samples for particle size determination were refrigerated and analysed within $4 \mathrm{~d}$ of collection. Previous tests 
had shown no change in particle size distribution in rumen DM refrigerated for $4 \mathrm{~d}$. Samples for chlorophyll determination were washed immediately and held in the dark at $4^{\circ}$ until analysis, within $4 \mathrm{~h}$ of collection.

Cows that were to be bailed during or after eating had samples of rumen fluid removed at 09.00 hours for background $\mathrm{Cr}$ determination, and $500 \mathrm{mg} \mathrm{Cr}$ (as the soluble marker CrEDTA) added per fistulum and mixed into rumen contents. $\mathrm{Cr}$ concentration was measured in bailed rumen contents at 10.00,10.30,11.30 and 13.30 hours, enabling rumen water outflow to be calculated over this period of time.

On days 3 and 7 of each experimental period, faeces were collected from each cow between 09.00 and 16.00 hours and subsampled for particle size analysis. Faeces were of a firm consistency and were scooped off clean rubber mats behind each cow at frequent intervals so that contamination with urine was avoided. Particles retained on the $0.25 \mathrm{~mm}$ and larger sieves were retained and combined within feeds for fibre analysis.

The time-period each cow spent ruminating was measured with a stopwatch between 11.30 and 13.30 hours on the day of 13.30 hours bailing.

\section{Feed sampling}

Feed samples were taken daily during the experimental period for DM determination $\left(24 \mathrm{~h}\right.$ at $95^{\circ}$ ), and additional samples were frozen, bulked and freeze-dried for chemical analysis. Chlorophyll content of fresh feed was determined daily. On three occasions during the lucerne experimental period $300 \mathrm{~g}$ feed $\mathrm{WM}$ were separated by hand into stem and leaf plus petiole fractions which were weighed and dried. A subsample of bulked lucerne was also separated into stem and leaf plus petiole fractions and freeze-dried for chemical analyses.

\section{Particle size analysis}

The particle size distributions of digesta and faeces were determined by a wet-sieving technique described by Waghorn (1986). A re-circulating flow of water was directed through a series of rotating sieves for $5 \mathrm{~min}$, separating material according to sieve aperture size. The sizes (length of side of square hole) were 4,2,1,0.5 and $0.25 \mathrm{~mm}$. Material passing the $0.25 \mathrm{~mm}$ sieve was centrifuged $(2000 \mathrm{~g}$ for $20 \mathrm{~min}$ ) and DM of the pellet determined. This fraction is termed 'residues'. DM not accounted for by sieve size or residue fractions is termed 'solubles' and was estimated by difference.

Because a large proportion of digesta DM was retained on the $4 \mathrm{~mm}$ sieve, especially with the ryegrass diet, this fraction was separated by hand into particles over and under $10 \mathrm{~mm}$ in length. This was done with samples from each cow from the 09.00 and 11.30 hours bailings with both feeds. Particles retained on the $4 \mathrm{~mm}$ sieve (including those over $10 \mathrm{~mm}$ in length) from prefeeding digesta were retained for fibre analysis.

\section{Chlorophyll release from feed}

The release of chlorophyll during and for $2 \mathrm{~h}$ after eating was calculated from the chlorophyll content of fresh feed and particulate rumen digesta. Feed chlorophyll was determined from a $5 \mathrm{~g}$ subsample of about $200 \mathrm{~g}$ feed chopped with scissors into $6 \mathrm{~mm}$ lengths. Chlorophyll in rumen particulate DM was determined after washing about $50 \mathrm{~g}$ rumen digesta through glass wool with $50-100 \mathrm{ml}$ saline $(9 \mathrm{~g}$ sodium chloride/1) until filtrate was clear. This removed free chloroplasts, chlorophyll and small DM material. A duplicate sample was washed and dried at $95^{\circ}$ for $24 \mathrm{~h}$ to determine the proportion of digesta DM that was used for chlorophyll extraction.

Chlorophyll was extracted from feed and washed rumen digesta by homogenizing in $50-100 \mathrm{ml}$ acetone-ethanol $(4: 1, \mathrm{v} / \mathrm{v})$. The homogenate was washed through glass wool, made up to a standard volume, and portions centrifuged before measuring absorbance at 
645 and $663 \mathrm{~nm}$ for the determination of chlorophyll content (Arnon, 1949). The amount of chlorophyll released from feed $(R)$ was calculated at each bailing from feed chlorophyll intake $(a)$, the prefeeding rumen-particulate chlorophyll pool $(b)$, the rumen-particulate chlorophyll pool at each bailing $(c)$, and the estimated particulate chlorophyll efflux from the rumen during eating $(d)$.

$$
R=a+b-c-d .
$$

Chlorophyll effiux during eating assumes that only particulate DM smaller than $2 \mathrm{~mm}$ was able to leave the rumen (Waghorn, 1986) and that this DM leaves with the water efflux, determined by CrEDTA dilution. This efflux was of minor significance, ranging between 0.2 and $0.9 \%$ of chlorophyll intake.

\section{Chemical analysis}

Feed nitrogen and lipid, and rumen fluid VFA and ammonia concentrations were determined using methods described by Waghorn (1986). Cellulose, hemicellulose and lignin in feeds and particulate matter from the rumen and faeces were determined by the method of Robertson \& Van Soest (1980). Feed samples were wet ashed in concentrated nitric acid and mineral elements determined by inductively coupled argon plasma spectrometry (Lee, 1981). Cr determinations in rumen fluid were by atomic absorption spectrometry (Binnerts et al. 1968).

\section{Statistical analyses}

Results were analysed by analysis of variance. The model included feeds, bailing times and sampling days as main effects, with a feed $\times$ bailing time interaction. The feed effect contains an unavoidable time effect due to different dates of maturation for lucerne and ryegrass. Faecal particle size analysis was by two-way analysis of variance. Values are presented as means with standard errors of the means.

\section{RESULTS}

\section{Feed composition}

Over the $10 \mathrm{~d}$ experimental period ryegrass and lucerne DM averaged 178 (SE 6.1) and 200 (SE 5.8$) \mathrm{g} / \mathrm{kg}$ respectively. The lucerne comprised $435 \mathrm{~g}$ leaf and petiole and $565 \mathrm{~g} \mathrm{stem} / \mathrm{kg}$ DM.

Chemical analyses of feeds (Table 1) showed large differences between chemical constituents of ryegrass and lucerne. Most noticeable was the low $\mathrm{N}$ content and high hemicellulose and cellulose contents of ryegrass compared with lucerne. Neutral-detergent fibre (NDF) components accounted for $569 \mathrm{~g} / \mathrm{kg}$ ryegrass DM and $394 \mathrm{~g} / \mathrm{kg}$ lucerne DM. Lucerne-stem DM contained $541 \mathrm{~g} \mathrm{NDF} / \mathrm{kg}$, so that about three-quarters of the total NDF and one-third of the total $\mathrm{N}$ was associated with the stem fraction and the remainder with the leaf.

Lucerne contained much higher concentrations of calcium and lower concentrations of sodium than ryegrass. The concentration of $\mathrm{Ca}$ and sulphur was much higher in lucerne leaf than stem (Table 1).

The chlorophyll content of lucerne $(5.81$ (SE 0.28) $\mathrm{g} / \mathrm{kg} \mathrm{DM}$ ) was $20 \%$ greater $(P<0.001)$ than that of ryegrass $(4.91$ (SE 0.11$) \mathrm{g} / \mathrm{kg} \mathrm{DM})$ during the experimental periods. Of lucerne chlorophyll $80 \%$ resided in the leaf plus petiole fraction.

\section{Intake and rumen pool size}

Table 2 summarizes intakes and rumen digesta pool sizes. Although both feeds were offered ad lib. for two $2 \mathrm{~h}$ periods each day, mean daily intakes and rates of DM intake were not different for the two feeds. WM intakes were higher $(P<0.01)$ with ryegrass because of its 
Table 1. Chemical composition of ryegrass (Lolium perenne L.) lucerne (Medicago sativa L.) and lucerne leaves and stems $(\mathrm{g} / \mathrm{kg}$ dry matter)

\begin{tabular}{lcccc}
\hline \hline & & \multicolumn{3}{c}{ Lucerne } \\
\cline { 3 - 5 } & & Whole & Leaf and \\
& Ryegrass & $\begin{array}{c}\text { Whant } \\
\text { petiole }\end{array}$ & Stem \\
\hline Nitrogen & $18 \cdot 6$ & $25 \cdot 8$ & $36 \cdot 9$ & $14 \cdot 7$ \\
Lipid & $40 \cdot 5$ & $39 \cdot 2$ & $49 \cdot 2$ & $25 \cdot 5$ \\
Cellulose & 283 & 210 & 121 & 311 \\
Hemicellulose & 269 & 135 & 129 & 153 \\
Lignin & $17 \cdot 2$ & $49 \cdot 4$ & $25 \cdot 7$ & $76 \cdot 7$ \\
Ash & $83 \cdot 8$ & 102 & 106 & $95 \cdot 5$ \\
Calcium & $3 \cdot 60$ & $12 \cdot 3$ & $17 \cdot 8$ & $8 \cdot 30$ \\
Potassium & $26 \cdot 3$ & $31 \cdot 5$ & $26 \cdot 4$ & $34 \cdot 1$ \\
Sodium & $2 \cdot 72$ & $0 \cdot 28$ & $0 \cdot 28$ & $0 \cdot 28$ \\
Sulphur & $3 \cdot 28$ & $3 \cdot 74$ & $5 \cdot 08$ & $2 \cdot 41$ \\
Chlorophyll & $4 \cdot 91$ & $5 \cdot 81$ & $10 \cdot 6$ & $2 \cdot 10$ \\
\hline \hline
\end{tabular}

high water content. There were no significant day effects on DM intake, rumen pool size, or other aspects of digestion within experimental periods.

When cows were fed on ryegrass the rumen DM pool was larger $(P<0.05)$ before eating (09.00 hours) and at the end of eating ( 11.30 hours), but at other times the difference between feeds was not significant. Rumen WM pool was larger $(P<0.01)$ when ryegrass was fed, compared with lucerne at all bailing times.

\section{Particle size distribution in the rumen}

The distribution of DM between particle size fractions is summarized in Table 3. Digesta from cows fed on ryegrass contained a greater proportion of DM retained on the 4 and $2 \mathrm{~mm}$ sieves $(323-511 \mathrm{~g} / \mathrm{kg} \mathrm{DM})$ than lucerne $(201-389 \mathrm{~g} / \mathrm{kg} \mathrm{DM} ; P<0.001)$. This fraction has a low probability of escape from the rumen (Waghorn, 1986) and accounts for only $6 \%$ of faecal DM (Table 4$)$.

DM retained on the $0.25,0.5$ and $1.0 \mathrm{~mm}$ sieves accounted for $110-360 \mathrm{~g} / \mathrm{kg}$ rumen DM, with ryegrass diets having a smaller proportion on the $0.5(P<0.001)$ and $1 \mathrm{~mm}(P<$ 0.001 ) sieves than lucerne. Residue and soluble DM accounted for $370-470 \mathrm{~g} / \mathrm{kg}$ total DM. Cows fed on ryegrass always had a lower proportion of residue DM $(P<0.001)$ and a higher proportion of soluble DM $(P<0.001)$ than when lucerne was given.

Hand separation of rumen digesta retained on the $4 \mathrm{~mm}$ sieve from the 09.00 hours (prefeeding) bailing showed $14 \%$ of ryegrass and $31 \%$ of lucerne DM on the $4 \mathrm{~mm}$ sieve to be over $10 \mathrm{~mm}$. This was equivalent to 42 (SE 4.7) and 48 (SE 9.3) $\mathrm{g} / \mathrm{kg}$ total DM for the respective feeds (not significant). At the 11.30 hours bailing the quantity of DM over 10 $\mathrm{mm}$ in length increased to $38 \%$ of that retained on the $4 \mathrm{~mm}$ sieve for ryegrass and $48 \%$ for lucerne, equivalent to 193 (SE 18.5) and 174 (SE 11.2) $\mathrm{g} / \mathrm{kg}$ rumen DM for the respective feeds (not significant).

\section{Faecal particle size distribution}

Distribution of faecal DM between particle size fractions is summarized in Table 4. Both diets resulted in similar proportions of faecal DM over $2 \mathrm{~mm}$ in size $(63 \mathrm{~g} / \mathrm{kg} \mathrm{DM})$, and similar proportions retained on 0.5 and $0.25 \mathrm{~mm}$ sieves, and in 'residues'. The proportion of DM retained on the $1.0 \mathrm{~mm}$ sieve was lower $(P<0.001)$ and 'soluble' DM higher $(P<$ 0.01 ) with ryegrass than lucerne faeces, as was the case with rumen digesta. 


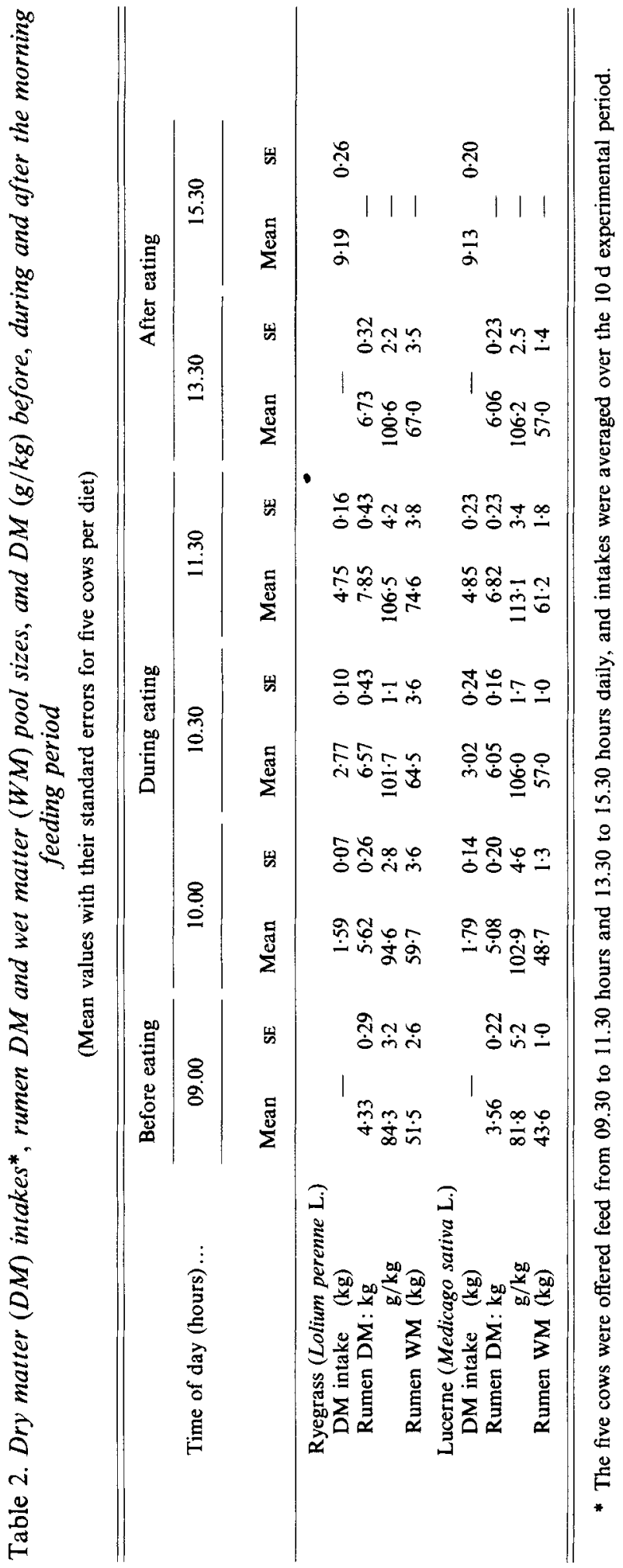


Table 3. Distribution of dry matter (DM) particles between different sieve sizes, 'residues' and 'solubles' $(\mathrm{g} / \mathrm{kg})$ in rumen DM of cows before, during and after the morning eating period*

(Values are means from individual bailing times)

\begin{tabular}{|c|c|c|c|c|c|c|c|}
\hline \multirow{2}{*}{$\begin{array}{l}\text { Time of day } \\
\text { (hours) ... }\end{array}$} & \multirow{2}{*}{$\begin{array}{c}\text { Before } \\
\text { eating } \\
09.00\end{array}$} & \multicolumn{3}{|c|}{ During eating } & \multirow{2}{*}{$\begin{array}{c}\text { After } \\
\text { eating } \\
13.30\end{array}$} & \multicolumn{2}{|c|}{ All bailings ( $n$ 25) } \\
\hline & & 10.00 & 10.30 & 11.30 & & Mean & $\mathbf{S E}$ \\
\hline \multicolumn{8}{|c|}{ Ryegrass (Lolium perenne L.) } \\
\hline $4 \mathrm{~mm}$ & 317 & 391 & 473 & 503 & 469 & 431 & $6 \cdot 1$ \\
\hline $2 \mathrm{~mm}$ & 5 & 8 & 6 & 8 & 10 & 7 & $1 \cdot 1$ \\
\hline $1 \mathrm{~mm}$ & 43 & 40 & 31 & 26 & 30 & 34 & $3 \cdot 3$ \\
\hline $0.5 \mathrm{~mm}$ & 82 & 67 & 58 & 43 & 48 & 59 & 6.9 \\
\hline $0.25 \mathrm{~mm}$ & 83 & 70 & 64 & 49 & 59 & 65 & $5 \cdot 1$ \\
\hline 'Residues' & 206 & 192 & 178 & 178 & 177 & 186 & $5 \cdot 5$ \\
\hline 'Solubles' & 263 & 232 & 191 & 193 & 210 & 218 & 13.5 \\
\hline \multicolumn{8}{|c|}{ Lucerne (Medicago sativa L.) } \\
\hline $4 \mathrm{~mm}$ & 162 & 290 & 339 & 356 & 312 & 292 & $9 \cdot 3$ \\
\hline $2 \mathrm{~mm}$ & 39 & 33 & 30 & 31 & 28 & 32 & $1 \cdot 7$ \\
\hline $1 \mathrm{~mm}$ & 136 & 106 & 91 & 80 & 89 & 100 & $9 \cdot 8$ \\
\hline $0.5 \mathrm{~mm}$ & 148 & 110 & 99 & 85 & 100 & 108 & $10 \cdot 7$ \\
\hline $0.25 \mathrm{~mm}$ & 81 & 69 & 65 & 75 & 70 & 72 & 2.8 \\
\hline 'Residues' & 239 & 213 & 210 & 217 & 255 & 227 & 8.6 \\
\hline 'Solubles' & 195 & 181 & 166 & 154 & 146 & 169 & 8.9 \\
\hline
\end{tabular}

* The five cows were offered feed from 09.30 to 11.30 hours and 13.30 to 15.30 hours daily.

Table 4. Distribution of dry matter (DM) between different sieve sizes, 'residues' and 'solubles' $(\mathrm{g} / \mathrm{kg} D M)$ in faeces of cows fed either on fresh ryegrass (Lolium perenne $L$.) or lucerne (Medicago sativa $L$.)

(Mean values with their standard errors for five cows per diet)

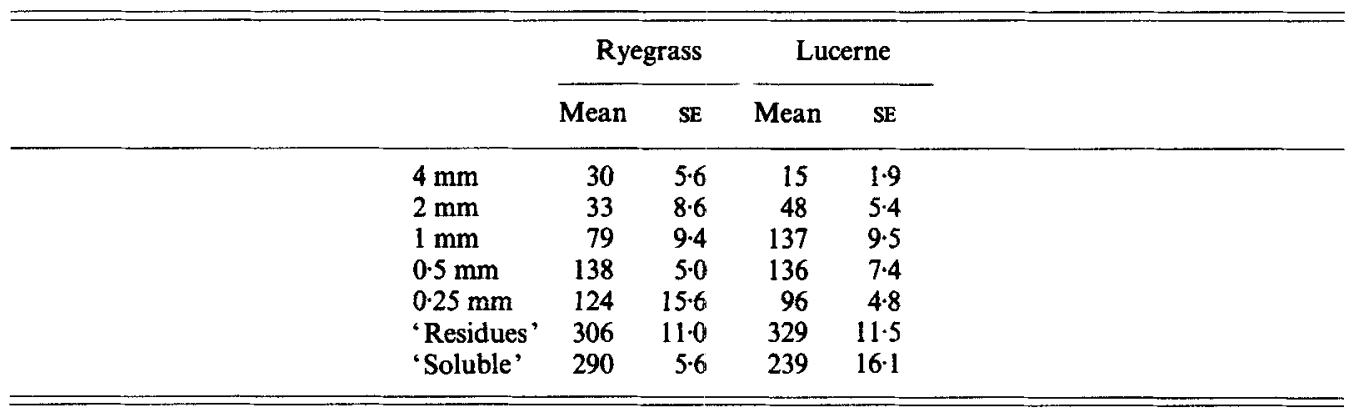

Particle size reduction and disappearance from the rumen

Feed consumption increased the proportion of rumen DM retained on the $4 \mathrm{~mm}$ sieve $(P<0.001)$. With ryegrass this increase was achieved by reducing the proportions of all smaller fractions, but with lucerne only the proportions retained on the $1 \mathrm{~mm}$ and $0.5 \mathrm{~mm}$ sieves were significantly $(P<0.001)$ reduced.

The effectiveness of chewing during eating has also been evaluated by calculating the quantity of DM reduced to a size able to pass a $2 \mathrm{~mm}$ sieve during and after eating. Because the rate of DM intake was more rapid $(P<0.001)$ during the first 30 min of eating with 
Table 5. Reduction* of dry matter (DM) retained on 2 and $4 \mathrm{~mm}$ sieves to sizes able to pass a $2 \mathrm{~mm}$ sieve during the first $30 \mathrm{~min}$ and the next $90 \mathrm{~min}$ of eating and for $120 \mathrm{~min}$ after the morning eating period

(Mean values with their standard errors for five cows per diet)

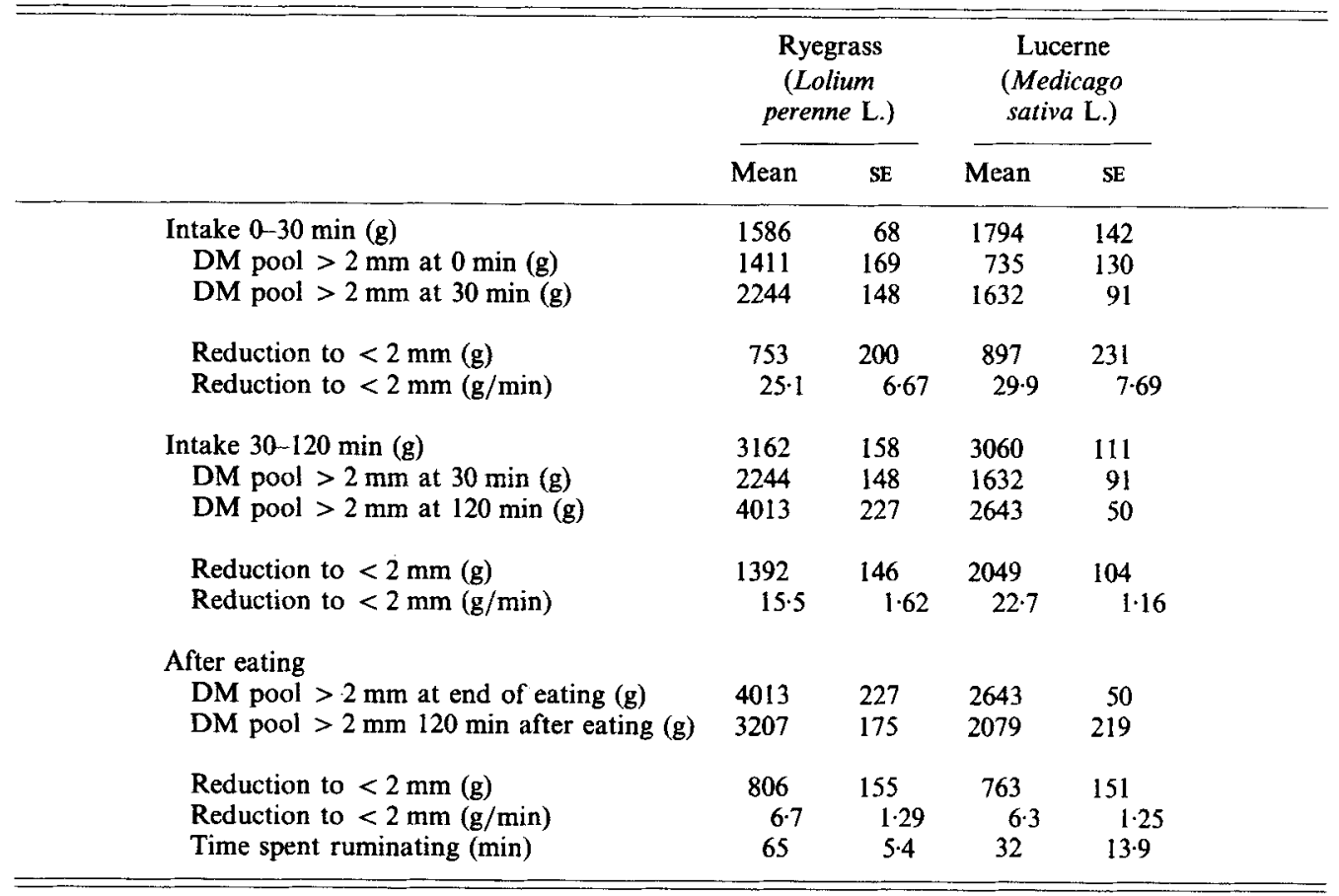

* Calculations are based on values from Tables 2 and 3, for example, reduction between 0 and 30 min of eating = rumen pool of particles retained on 2 and $4 \mathrm{~mm}$ sieves at time $0+$ DM intake from 0 to 30 min - rumen pool of DM retained on 2 and $4 \mathrm{~mm}$ sieves after $30 \mathrm{~min}$ of eating.

both feeds $(53-60 \mathrm{~g} / \mathrm{min})$ compared with the following $90 \mathrm{~min}(34-35 \mathrm{~g} / \mathrm{min})$, values for these periods are presented separately (Table 5).

During the first $30 \mathrm{~min}$ of eating, similar proportions of lucerne $(0.50)$ and ryegrass $(0.47)$ were reduced to a size able to pass a $2 \mathrm{~mm}$ sieve (not significant). Over the next $90 \mathrm{~min}$, when rates of intake were slower (Table 2$)$, significantly $(P<0.01)$ more of the lucerne was reduced to pass a $2 \mathrm{~mm}$ sieve (0.67) compared with ryegrass $(0.46)$. In the $2 \mathrm{~h}$ after eating, the rate of particle size reduction was similar for both feeds (6.3-6.7 $\mathrm{g} \mathrm{DM} / \mathrm{min})$ and much slower than during the eating period (lucerne $24.6 \mathrm{~g} \mathrm{DM} / \mathrm{min}$, ryegrass $17.9 \mathrm{~g} \mathrm{DM} / \mathrm{min}$ ). Time-period spent ruminating was greater $(P<0 \cdot 10)$ when cows were fed on ryegrass than when fed on lucerne, but variation between cows was high (Table 5).

A high proportion of large particulate DM in prefeeding digesta, combined with less effective reduction in ryegrass particle size during eating, resulted in a much larger DM pool unable to pass a $2 \mathrm{~mm}$ sieve at 11.30 hours $(4.01 \mathrm{~kg})$ than with lucerne $(2.64 \mathrm{~kg} ; P<$ 0.001). Particles retained on the $4 \mathrm{~mm}$ sieve accounted for most of this pool (Table $3)$.

At 09.00 hours, rumen particles on the $4 \mathrm{~mm}$ sieve contained $883-911 \mathrm{~g} \mathrm{NDF} / \mathrm{kg} \mathrm{DM}$ (Table 6). Faecal DM retained on the $0.25 \mathrm{~mm}$ and larger sieves contained $837-853 \mathrm{~g}$ NDF/kg DM (Table 6). 
Table 6. Fibre components in rumen particulate dry matter $(D M ; g / k g ~ D M)$ retained on a $4 \mathrm{~mm}$ sieve and sampled before eating, and in faecal particulate DM retained on the $0.25 \mathrm{~mm}$ and larger sieves

(Analyses are based on combined samples from five cows)

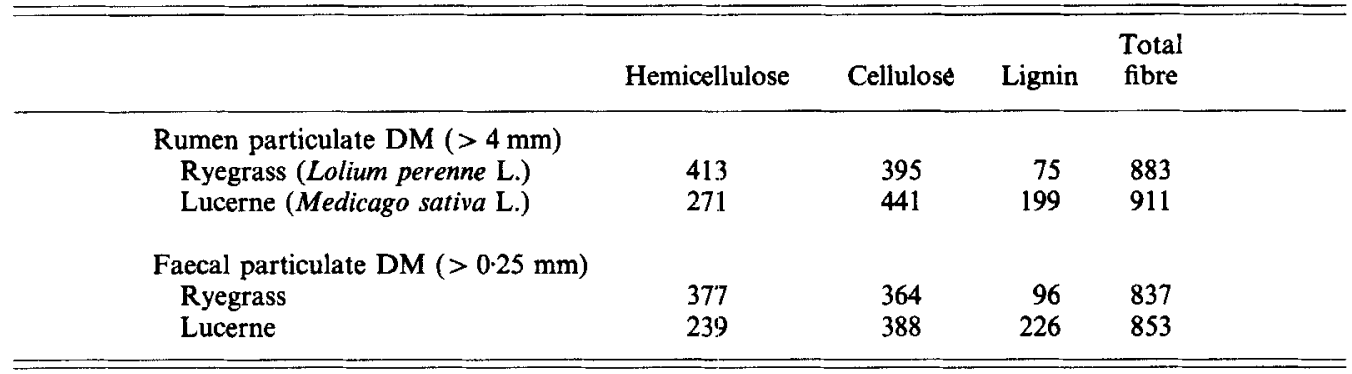

Water fluxes

Changes in $\mathrm{Cr}$ concentration and digesta water pool size enabled rumen water outflow to be calculated during and for $2 \mathrm{~h}$ after eating. When ryegrass was given the outflow was $10 \cdot 3$ (SE 0.93) and 10.2 (SE 1.65) litres/h during and after eating respectively. With lucerne the outflow during eating (12.7 (SE 1.31) litres/h) was similar to that with ryegrass, but after eating the flow was significantly slower $(6.0$ (SE 0.54$)$ litres $/ \mathrm{h} ; P<0.01)$ and slower $(P<$ $0.05)$ than the corresponding period with the ryegrass diet.

Change in rumen water pools determined by bailing, in conjunction with feed-water intake and calculated outflow, enabled net endogenous water fluxes into the rumen to be estimated. When ryegrass was given, rates were similar during eating ( $9 \cdot 2$ (SE 1.69) litres/ h) and after eating (7.0 (SE 1.44) litres/h). With the lucerne diet endogenous input during eating $(9.0$ (SE 1.52) litres/h) was greater than during $2 \mathrm{~h}$ after eating (4.2 (SE 1.04) litres/ h; $P<0.05)$.

\section{Chlorophyll release}

During the morning feeding period the total intake of chlorophyll averaged 23.5 and $28.2 \mathrm{~g}$ when cows were fed on ryegrass and lucerne respectively. The cumulative percentage release of chlorophyll from ingested feed was calculated during and after eating.

The cumulative percentage chlorophyll release at the end of eating (11.30 hours) was 57.0 (SE 4.34 ) \% for ryegrass and 60.7 (SE 2.36) \% for lucerne (not significant). By 13.30 hours the cumulative release from ryegrass had increased slightly to 63.8 (SE $2 \cdot 13$ ) \% of intake (not significant) and to $79 \cdot 1$ (SE 1.74$) \%$ for lucerne, which was significantly $(P<0.01)$ greater than that at 11.30 hours. Amounts released by 13.30 hours were $15.0 \mathrm{~g}$ for ryegrass and $22.3 \mathrm{~g}$ for lucerne $(P<0 \cdot 001)$.

Calculations of chlorophyll released at 10.00 and 10.30 hours have a higher standard error and are probably less meaningful. With lucerne 39.6 (SE 8.79) \% was released at 10.00 hours and $49 \cdot 7$ (SE 6.73) \% at 10.30 hours. Ryegrass values were 55.0 (SE 5.97) \% at 10.00 hours and 42.6 (SE 8.09) \% at 10.30 hours. The apparent decrease in cumulative release between 10.00 and 10.30 hours is not possible, and suggests an overestimate at 10.30 hours.

\section{$V F A$ and ammonia concentration and $p H$ of rumen contents}

Significant increases in VFA concentration during eating occurred with both feeds $(P<$ 0.001 ; Table 7). Compared with ryegrass, lucerne resulted in higher $(P<0.001)$ rumen VFA concentrations at all times except prefeeding, when the reverse was true $(P<0.01)$, but feed effects on rumen $\mathrm{pH}$ were only significant $(P<0.01)$ prefeeding (Table 7$)$. 
Table 7. Concentrations (mmol/l) of ammonia, volatile fatty acids (VFA) and the acidity $(p H)$ of rumen fluid from cows fed on ryegrass (Lolium perenne L.) or lucerne (Medicago sativa $L$.) before, during and after the morning feeding period*

(Mean values with their standard errors for five cows per diet)

\begin{tabular}{|c|c|c|c|c|c|c|c|c|c|c|}
\hline \multirow{3}{*}{$\begin{array}{l}\text { Time of day } \\
\text { (hours) ... }\end{array}$} & \multirow{2}{*}{\multicolumn{2}{|c|}{$\begin{array}{c}\text { Before } \\
\text { eating } \\
09.00\end{array}$}} & \multicolumn{6}{|c|}{ During eating } & \multirow{2}{*}{\multicolumn{2}{|c|}{$\begin{array}{c}\text { After } \\
\text { eating } \\
13.30\end{array}$}} \\
\hline & & & \multicolumn{2}{|c|}{10.00} & \multicolumn{2}{|c|}{10.30} & \multicolumn{2}{|c|}{11.30} & & \\
\hline & Mean & SE & Mean & SE & Mean & $\mathrm{SE}$ & Mean & $\mathbf{S E}$ & Mean & $\mathrm{SE}$ \\
\hline \multicolumn{11}{|l|}{ Ryegrass } \\
\hline Ammonia & $8 \cdot 3$ & 0.22 & 103 & 0.53 & $10 \cdot 6$ & 0.84 & $12 \cdot 2$ & 0.61 & $9 \cdot 6$ & $0 \cdot 84$ \\
\hline VFA & $89 \cdot 7$ & $2 \cdot 32$ & $92 \cdot 5$ & $2 \cdot 28$ & $102 \cdot 0$ & 3.42 & $110 \cdot 9$ & 5.58 & 116.7 & $6 \cdot 22$ \\
\hline $\mathrm{pH}$ & $6 \cdot 9$ & 0.04 & 6.8 & 0.07 & $6 \cdot 8$ & 0.06 & 6.5 & 0.15 & 6.5 & $0 \cdot 11$ \\
\hline \multicolumn{11}{|l|}{ Lucerne } \\
\hline Ammonia & $9 \cdot 5$ & 0.74 & $13-1$ & 0.93 & $16 \cdot 2$ & 2.03 & $20 \cdot 3$ & 1.42 & 21.6 & $2 \cdot 49$ \\
\hline VFA & $74 \cdot 1$ & 3.62 & $96-7$ & $2 \cdot 87$ & 116.7 & 3.93 & $142 \cdot 4$ & $5 \cdot 16$ & $150 \cdot 2$ & 6.54 \\
\hline $\mathrm{pH}$ & $7 \cdot 1$ & 0.03 & 6.7 & 0.06 & $6 \cdot 6$ & 0.04 & $6 \cdot 3$ & 0.08 & $6 \cdot 3$ & $0 \cdot 11$ \\
\hline
\end{tabular}

* The five cows were offered feed from 09.30 to 11.30 hours and 13.30 to 15.30 hours daily.

Mean ammonia concentration was higher $(P<0.001)$ with lucerne $(16.1 \mathrm{mmol} / \mathrm{l})$ than with ryegrass $(10.2 \mathrm{mmol} / 1)$, and increased during eating with both feeds $(P<0.001$; Table 7). After eating (13.30 hours) ammonia concentration declined $(P<0.01)$ in cows fed on ryegrass, but was unchanged with lucerne.

Molar proportions of acetate, butyrate and isovalerate in total VFA did not change during or after feeding. The molar proportions of propionate increased $(P<0.01)$ from 0.165 of VFA prefeeding to 0.221 of VFA at 11.30 hours with lucerne, and minor increases $(P<0.05)$ in the molar proportions of valerate occurred with both feeds. Molar proportions of acetate, propionate, butyrate, isovalerate and valerate, averaged over the five bailing times, were $0.63,0.20,0.13,0.02$ and 0.02 for ryegrass and $0.63,0.19,0.15,0.02$ and 0.01 for lucerne respectively. Lucerne had a higher proportion of butyrate $(P<0.01)$ and a lower proportion of valerate $(P<0.05)$ than ryegrass but proportions of other VFA were similar for both diets.

\section{DISCUSSION}

The principal observation in the present experiment was the slower breakdown, clearance and fermentation in the rumen of cows fed on ryegrass compared with lucerne. This discussion clarifies the upper limit to size of particles able to exit from the cow rumen, and compares rates of disappearance of different size particle fractions for both feeds. Rumen clearance of lucerne stem and whole ryegrass are also compared in relation to their chemical and physical composition, and some aspects of lucerne digestion are discussed in relation to bloat.

It is important to realize that although particle size is frequently indicated by sieve aperture size, particles are able to pass through the sieve lengthwise, and be longer than the sieve aperture size. Studies at this laboratory with sheep rumen digesta have shown the mean length of particles ( $n 200-300$ ) passing a $2 \mathrm{~mm}$ sieve and retained on a $1 \mathrm{~mm}$ sieve to be $3.54 \mathrm{~mm}$ (fresh ryegrass) and $3.36 \mathrm{~mm}$ (fresh lucerne; K. Kelly, personal communication). A similar relation has been shown for particles passing sieves with larger and smaller aperture sizes, so that wet sieving allows particles with a length of about 1.8 times the sieve aperture to pass. 


\section{Particle outflow from the rumen}

Passage of digesta is influenced by the upper limit to the size of particles able to leave the rumen. In sheep most particles leaving the rumen are able to pass a $1 \mathrm{~mm}$ sieve (e.g. Ulyatt et al. 1986), but there is some argument about the size of particles able to leave the rumen of cattle. Poppi et al. (1985) considered there to be no justification for using different threshold particle sizes for sheep and cattle, and suggested an upper limit to passage of about $1 \mathrm{~mm}$. Results from the present experiment are in conflict with their conclusions.

The particle size distribution of faecal DM in the present experiment showed material retained on the 1, 2 and $4 \mathrm{~mm}$ sieves was $14.2 \%$ of faecal DM for ryegrass and $20.0 \%$ for lucerne but only $6.3 \%$ of faecal DM was retained on the 2 and $4 \mathrm{~mm}$ sieves for both feeds. Grenet (1970) showed 10-15\% of faecal DM from cattle fed on fresh pasture were retained on a $1 \mathrm{~mm}$ sieve, and Waghorn (1986) reported $18.2 \%$ of faecal DM from cows fed on lucerne hay were retained on 1,2 and $4 \mathrm{~mm}$ sieves. These findings show a significant portion of DM passing out of the cow rumen is retained on the $1 \mathrm{~mm}$ sieve, but few particles are retained on the 2 and $4 \mathrm{~mm}$ sieves. The difference between cattle and sheep is further evidenced by studies showing the mean particle size of sheep faeces to be about half that for cattle (Thomas \& Campling, 1977; Uden \& Van Soest, 1982).

There is little reduction in the size of particulate DM after it leaves the rumen (Uden \& Van Soest, 1982; Poppi et al. 1985) so the size distribution of faecal DM can be used to calculate the relative resistance to passage from the rumen for different size DM fractions. Poppi et al. (1985) have done this for several size fractions by expressing the proportion in rumen and faecal DM relative to a small size fraction which should be able to leave the rumen unhindered. The small iraction is given a value of 1.0 , and the probability of passage of other fractions is expressed relative to $1 \cdot 0$.

In the present experiment DM passing the $0.5 \mathrm{~mm}$ sieve and retained on the $0.25 \mathrm{~mm}$ sieve was given a resistance of $1 \cdot 0$. For the ryegrass diet the relative resistance to passage of 'soluble' and 'residue 'DM, and that retained on 0.25, 0.5, 1.0, 2.0 and 4.0 mm sieves was calculated to be $1.43,1 \cdot 16,1 \cdot 0,0.82,0.82,0.40$ and 27.4 respectively. For lucerne the values were $0.94,0.92,1.0,1.06,0.97,0.89$ and 26.0 respectively. These values show that for both diets there was a similar probability of passage from the rumen of 'soluble', 'residue' and all particulate fractions up to and including that retained on the $2 \mathrm{~mm}$ sieve. However, particles retained on the $2 \mathrm{~mm}$ sieve represented a very small portion of rumen DM (Table 3 ), and their high probability of passage from the rumen should be treated with caution.

This result is similar to findings with steers fed on grass hay (Dixon \& Milligan, 1981), but is quite different from the results of Poppi et al. (1985) when cattle were fed on dried tropical forages. Poppi et al. (1985) based their calculation on particles passing a $0.3 \mathrm{~mm}$ sieve and retained on a $0.15 \mathrm{~mm}$ sieve having a resistance to passage from the rumen of 1.0 , and the relative resistance to passage of particles retained on $0.15,0.3,0.5,1.18,2.36$ and $4.75 \mathrm{~mm}$ sieves were $1 \cdot 0,1 \cdot 0,2 \cdot 1,11 \cdot 0,40 \cdot 8$ and infinity, respectively. Only $3.4 \%$ of faecal DM were retained on a $1.18 \mathrm{~mm}$ sieve.

It appears that either tropical forages are broken down and digested in the rumen in a manner different from that for temperate forages, or that the difference may lie in the breed of cattle used. Poppi et al. $(1980,1985)$ have not indicated whether their cattle were Bos indicus or Bos taurus. If they used Bos indicus cattle to evaluate their tropical forages, then genetic differences between Bos indicus and Bos taurus may have been important in affecting particle size movement out of the rumen. 
Table 8. Proportions of the rumen dry matter (DM) pool unable to pass a $2 \mathrm{~mm}$ sieve in relation to cumulative DM intake of ryegrass (Lolium perenne $L$.), lucerne (Medicago sativa $L$.) and lucerne stem* before $\dagger$, during and after the morning eating period $\ddagger$

(Mean values with their standard errors for five cows per diet)

\begin{tabular}{|c|c|c|c|c|c|c|c|c|c|c|}
\hline \multirow{3}{*}{$\begin{array}{l}\text { Time of day } \\
\text { (hours)... }\end{array}$} & \multirow{2}{*}{\multicolumn{2}{|c|}{$\begin{array}{l}\text { Before } \\
\text { eating } \\
09.00\end{array}$}} & \multicolumn{6}{|c|}{ Eating } & \multirow{2}{*}{\multicolumn{2}{|c|}{$\begin{array}{c}\text { After } \\
\text { eating } \\
13.30\end{array}$}} \\
\hline & & & \multicolumn{2}{|c|}{10.00} & \multicolumn{2}{|c|}{10.30} & \multicolumn{2}{|c|}{11.30} & & \\
\hline & Mean & SE & Mean & $\mathbf{S E}$ & Mean & $\mathrm{SE}$ & Mean & $\mathrm{SE}$ & Mean & $\mathbf{S E}$ \\
\hline Ryegrass & $0 \cdot 15$ & 0.015 & 1.41 & 0.095 & $1 \cdot 14$ & 0.082 & 0.85 & 0.023 & 0.68 & 0.023 \\
\hline Lucerne stem & 0.14 & 0.023 & 1.65 & 0.148 & 1.31 & 0.076 & 0.96 & 0.031 & 0.75 & 0.045 \\
\hline Lucerne & 0.08 & 0.013 & 0.93 & 0.084 & 0.74 & 0.043 & 0.54 & 0.018 & 0.42 & 0.026 \\
\hline
\end{tabular}

* Stem accounted for $565 \mathrm{~g} / \mathrm{kg}$ lucerne DM.

+ Before feeding is the same as $24 \mathrm{~h}$ post onset of feeding.

$\ddagger$ The five cows were offered feed from 09.30 to 11.30 hours and 13.30 to 15.30 hours daily.

\section{Particle size reduction and clearance}

Rumen clearance has a major influence on forage DM intake (Western, 1985). The rate at which the rumen in cleared of forage DM is determined in part by the release and fermentation of plant-cell constituents, but the effectiveness with which chewing is able to reduce the particle size of fibrous residues (Ulyatt et al. 1986) appears to be most important. Clearance of forage diets is therefore largely determined by the cell-wall content and cellwall composition of the diet (Doyle, 1985).

In the present study chewing during eating reduced $61 \%$ of lucerne DM but only $46 \%$ of ryegrass DM to a size able to pass a $2 \mathrm{~mm}$ sieve. The higher resistance of ryegrass to breakdown is further indicated by the increase to $51 \%$ of rumen DM unable to pass a $2 \mathrm{~mm}$ sieve by 11.30 hours (Table 3 ). The slow clearance of ryegrass is indicated by the larger prefeeding DM pool which was $47 \%$ of daily intake (cf. $39 \%$ of daily intake for lucerne).

The particle size reduction of lucerne during eating can be examined in terms of the breakdown of stem and leaf. Stem accounted for $56.5 \%$ of lucerne DM, and leaf for $43.5 \%$ of lucerne DM. The rate at which lucerne stem was broken down appeared similar to that for whole ryegrass. This can be illustrated by relating the proportion of rumen DM unable to pass a $2 \mathrm{~mm}$ sieve to the intake of either lucerne stem or whole ryegrass at that time. For example, the proportion of prefeeding DM unable to pass the $2 \mathrm{~mm}$ sieve in relation to daily intake of lucerne stem $(0.74 \mathrm{~kg} / 5.15 \mathrm{~kg}=0.15)$ is very similar to that for ryegrass $(1.49 \mathrm{~kg} / 9.19 \mathrm{~kg}=0.14)$. Table 8 summarizes this relation for all bailing times; however, the ratios for lucerne stem and ryegrass would have been closer at 10.00,10.30 and 11.30 hours if the small amount of lucerne leaf had been removed from the 2 and $4 \mathrm{~mm}$ sieves.

Chemical analyses support the likeness of lucerne stem and whole ryegrass. Ryegrass DM contained $18.6 \mathrm{~g} \mathrm{~N}$ and $569 \mathrm{~g} \mathrm{NDF} / \mathrm{kg} \mathrm{DM}$, compared with $14.7 \mathrm{~g} \mathrm{~N}$ and $541 \mathrm{~g} \mathrm{NDF} /$ $\mathrm{kg}$ DM for lucerne stem. Differences in components of NDF, i.e. the higher proportion of lignin and lower proportion of hemicellulose in lucerne stem (Table 1), and differences in anatomical configuration of fibre bundles in ryegrass and lucerne stem had no net effect on breakdown and clearance of either component from the rumen.

At 09.00 hours rumen DM retained on the $4 \mathrm{~mm}$ sieve was predominantly fibre (Table 6). Faecal particulate DM was also predominantly fibre, so the rate of physical breakdown 
Table 9. Net increase* $(g)$ in the rumen pool of 'soluble' and 'residue' dry matter (DM) during and after the morning eating period $\dagger$

\begin{tabular}{|c|c|c|c|c|}
\hline \multirow[b]{2}{*}{ Time of day (hours) ... } & \multicolumn{3}{|c|}{ Eating } & \multirow{2}{*}{$\begin{array}{l}\text { After } \\
\text { eating } \\
13.30\end{array}$} \\
\hline & 10.00 & 10.30 & 11.30 & \\
\hline $\begin{array}{l}\text { 'Soluble' DM } \\
\text { Ryegrass } \\
\text { (Lolium perenne } \mathrm{L} . \text {.) }\end{array}$ & 164 & 116 & 376 & 274 \\
\hline $\begin{array}{l}\text { Lucerne } \\
\text { (Medicago sativa } \mathrm{L} \text {.) }\end{array}$ & 225 & 310 & 356 & 191 \\
\hline $\begin{array}{l}\text { 'Residue' DM } \\
\text { Ryegrass } \\
\text { Lucerne }\end{array}$ & $\begin{array}{l}187 \\
229\end{array}$ & $\begin{array}{l}277 \\
419\end{array}$ & $\begin{array}{l}505 \\
629\end{array}$ & $\begin{array}{l}299 \\
649\end{array}$ \\
\hline
\end{tabular}

* The increase is the pool size less that at 09.00 hours.

$\dagger$ The five cows were offered feed from 09.30 to 11.30 hours and 13.30 to 15.30 hours daily.

appeared to be the principal limitation to clearance of this material from the rumen, with both feeds.

One consequence of the high fibre content of ryegrass is that less DM is available for release into the highly fermentable 'soluble' and 'residue' pools during eating. In contrast, very little lucerne leaf was evident on the 2 and $4 \mathrm{~mm}$ sieves during eating, suggesting an effective rupture and release of DM during eating (Howarth et al. 1982; Kudo et al. 1985). Lucerne leaf contained a high proportion of the water-soluble sugars, organic acids, pectin, chloroplasts and much of the soluble plant protein (Mangan, 1982), and must account for the large increase in 'soluble' and 'residue' DM pools during the 1st hour of feeding. This increase was nearly double that for ryegrass (Table 9), and was accompanied by a very rapid increase in rumen VFA and ammonia concentrations, and a rapid decline in $\mathrm{pH}$ with the lucerne diet.

\section{Implications for bloat}

The decline in $\mathrm{pH}$ with feeding may have significant implications with regard to bloat. Although a high rate of gas production from fermentation is considered a prerequisite (but not a cause) for bloat (Clarke \& Reid, 1974), the volume of carbon dioxide released from rumen bicarbonate in association with declining $\mathrm{pH}$ may be of significance. The theoretical $\mathrm{CO}_{2}$ release during the 1 st hour of feeding, based on calculations by Kleiber (Cole et al. 1945), was 102 litres for lucerne and 29 litres for ryegrass. In addition about 1 litre gas/min is likely to arise from the fermentation of newly ingested feed, and should enhance the likelihood of foam formation with lucerne, compared with ryegrass.

The occurrence of bloat has been correlated with release of plant chloroplasts (Reid et al. 1962; Stifel et al. 1968) and the concentration of fraction 1 plant protein (EC 4.1.1.39) in rumen fluid (Jones et al. 1970, 1978; Howarth et al. 1977). Bloat has also been related to the rate of cell-wall disintegration in both red clover (Trifolium pratense) (Sant \& Wilson, 1982) and lucerne (Howarth et al. 1982). It was therefore surprising that similar proportions of plant chlorophyll were released from both ryegrass and lucerne during eating, in view of the lower NDF and the more effective particle size reduction of lucerne. However, the continued release of chlorophyll from lucerne after eating was probably due to the rapid degradation of the chlorophyll-rich leaf fraction (Howarth et al. 1982).

The higher concentration of chlorophyll in lucerne combined with a smaller rumen WM 
pool at 11.30 hours suggests a higher chloroplast concentration in lucerne rumen fluid, especially as outflow of water from the rumen was similar for both feeds. Calculated concentrations at 11.30 hours (uncorrected for flux to the abomasum) were 19.9 and $31.4 \mathrm{mg} / \mathrm{l}$ for ryegrass and lucerne respectively. This difference would be compatible with an involvement of chloroplasts in foam stability and bloat, although their mode of action has not been established.

\section{Conclusion}

The rapid physical breakdown of lucerne leaf to a size able to pass from the rumen, together with its high protein content, will enable more feed protein to reach and be digested in the intestines of cows fed on lucerne than those fed on ryegrass. This will contribute to the higher nutritive value of lucerne (Hogan, 1982), whilst the rapid clearance of leaf DM will enable a higher intake of lucerne when feed is available under true ad lib. conditions. The principal limitation to a high nutritive value of ryegrass is its high resistance to particle breakdown and consequently rumen clearance. The rapid degradation of lucerne leaf may also be a main disposing factor in the establishment of bloat, and this may be exacerbated by intermittent feeding.

The assistance of Mr J. Kook for feeding and bailing the cows, and $\mathrm{Mr} \mathrm{T}$. Gerson for guidance with VFA analyses is gratefully acknowledged, also Catherine Gurnsey and Anne Allan for chemical analysis of feeds.

\section{REFERENCES}

Arnon, D. I. (1949). Copper enzymes in isolated chloroplasts. Plant Physiology 24, 1-15.

Balch, C. C. \& Cowie, A. T. (1962). Permanent rumen fistulae in cattle. Cornell Veterinarian 52, $206-214$.

Binnerts, W. T., Vant Klooster, A. Th. \& Frens, A. N. (1968). Soluble chromium indicator measured by atomic absorption in digestion experiments. Veterinary Record $82 ; 470$.

Clarke, R. T. J. \& Reid, C. S. W. (1974). Foamy bloat of cattle. A Review, Journal of Dairy Science 57, 753-785.

Cole, H. H., Huffman, C. F., Kleiber, M., Olson, T. M. \& Schalk, A. F. (1945). A review of bloat in ruminants. Journal of Animal Science 4, 183-236.

Dixon, R. M. \& Milligan, L. P. (1981). Turnover of small particles in the rumen. Canadian Journal of Animal Science 61 Abstr., 1108.

Doyle, P. T. (1985). Fibre intake, digestion and flow rates in sheep. In Rumen Physiology-Concepts and Consequences, pp. 105-116 [S. K. Baker, J. M. Gawthorne, J. B. Mackintosh and D. B. Purser, editors]. Perth: University of Western Australia.

Grenet, E. (1970). Taille et structure des particules végétales au niveau du feuillet et des feces chez les bovins. Annals of Biology, Animal Biochemistry and Biophysics 10, 643-657.

Hogan, J. P. (1982). Digestion and utilization of proteins. In Nutritional Limits to Animal Production from Pastures, pp. 245-257 [J. B. Hacker, editor]. Farnham Royal: Commonwealth Agricultural Bureaux.

Howarth, R. E., Cheng, K.-J., Majak, W. \& Costerton, J. W. (1986). Ruminant bloat. In Control of Digestion and Metabolism in Ruminants, pp. 516-527 [L. P. Milligan, W. L. Grovum and A. Dobson, editors]. Englewood Cliffs, New Jersey: Prentice-Hall.

Howarth, R. E., Goplen, B. P., Brandt, S. A. \& Cheng, K.-J. (1982) Disruption of leaf tissues by rumen microorganisms: an approach to breeding bloat safe forage legumes. Crop Science, 22, 564-568.

Howarth, R. E., Sarkar, S. K., Fesser, A. C. \& Schnarr, G. W. (1977). Some properties of soluble proteins from alfalfa (Medicago sativa) herbage and their possible relationship to ruminant bloat. Journal of Agriculture and Food Chemistry 25, 175-179.

Jones, W. T., Lyttleton, J. W. \& Clarke, R. T. J. (1970). Bloat in cattle. XXXIII. The soluble proteins of legume forages in New Zealand, and their relationship to bloat. New Zealand Journal of Agricultural Research 13, $149-156$.

Jones, W. T., Lyttleton, J. W. \& Mangan, J. L. (1978). Interactions between Fraction 1 leaf protein and other surfactants involved in the bloat syndrome 1. Foam stabilising materials. New Zealand Journal of Agricultural Research 21, 401-407.

Kudo, H., Cheng, K.-J., Hanna, M. R., Howarth, R. E., Goplen, B. P. \& Costerton, J. W. (1985). Ruminal digestion of alfalfa strains selected for slow and fast initial rates of digestion. Canadian Journal of Animal Science 65, 157-161. 
Lee, J. (1981). Evaluation of the inductively-coupled argon plasma emission spectrometer during 'bedding in' and its performance in the analyses of biological materials. Applied Biochemistry Division, DSIR Technical Report No. 3. Palmerston North, New Zealand: Applied Biochemistry Division, DSIR.

Majak, W., Hall, J. W., Rode, L. M. \& Kalnin, C. C. (1986). Rumen clearance rates in relation to the occurrence of alfalfa bloat in cattle. I. Passage of water soluble markers. Journal of Dairy Science, 69, 1560-1567.

Majak, W., Howarth, R. E. \& Narasimhalu, P. (1985). Chlorophyll and protein levels in bovine rumen fluid in relation to alfalfa pasture bloat. Canadian Journal of Animal Science 65, 147-156.

Mangan, J. L. (1982). The nitrogenous constituents of fresh forages. In Forage Protein in Ruminant Animal Production. British Society of Animal Production. Occasional Publication No. 6, pp. 25-40 [D. J. Thomson, D. E. Beever and R. G. Gunn, editors]. Thames Ditton: British Society of Animal Production.

Poppi, D. P., Hendricksen, R. E. \& Minson, D. J. (1985). The relative resistance to escape of leaf and stem particles from the rumen of cattle and sheep. Journal of Agricultural Science, Cambridge 105, 9-14.

Poppi, D. P., Norton, B. W., Minson, D. J. \& Hendricksen, R. E. (1980). The validity of the critical size theory for particles leaving the rumen. Journal of Agricultural Science, Cambridge 94, 275-280.

Reid, C. S. W., Lyttleton, J. W. \& Mangan, J. L. (1962). Bloat in cattle. XXIV. A method of measuring the effectiveness of chewing in the release of plant cell contents from ingested feed. New Zealand Journal of Agricultural Research 5, 237-248.

Robertson, J. B. \& Van Soest, P. J. (1980). The detergent system of analyses and its application to human foods. In Basic and Clinical Nutrition, vol 3, pp. 123-158 [W.P. T. James and O. Theander, editors]. New York: Marcel Dekker.

Sant, F. I. \& Wilson, D. (1982). Use of a cellulolytic enzyme digestion technique to distinguish bloat-causing from non-bloat-causing legumes and to select for speed of mesophyll cell-wall disintegration in red clover (Trifolium pratense L.). Journal of Agricultural Science, Cambridge 98, 99-102.

Stifel, F. B., Vetter, R. L., Allen, R. S. \& Horner, H. T. (1968). Chemical and ultrastructural relationships between alfalfa leaf chloroplasts and bloat. Phytochemistry 7, 355-364.

Sukachi, R. \& Hoshino, S. (1981). Microbial characteristics of ruminal fluid from feedlot bloat beef cattle. Journal of General and Applied Microbiology 27, 145-155.

Thomas, S. \& Campling, R. C. (1977). Comparisons of some factors affecting digestibility in sheep and cows. Journal of the British Grassland Society 32, 33-41.

Uden, P. \& Van Soest, P. J. (1982). The determination of digesta particle size in some herbivores. Animal Feed Science and Technology 7, 35-44.

Ulyatt, M. J. (1981). The feeding value of herbage: can it be improved? New Zealand Agricultural Science 15, 200-205.

Ulyatt, M. J., Dellow, D. W., John, A., Reid, C. S. W. \& Waghorn, G. C. (1986). Contribution of chewing during eating and rumination to the clearance of digesta from the rumino-reticulum. In Control of Digestion and Metabolism in Ruminants, pp. 498-515 [L. P. Milligan, W. L. Grovum and A. Dobson, editors] Englewood Cliffs, New Jersey: Prentice-Hall.

Waghorn, G. C. (1986). Changes in rumen digesta of cows during a restricted eating period when fed fresh red clover, lucerne or lucerne hay. New Zealand Joumal of Agricultural Research 29, 233-241.

Western, R. H. (1985). The regulation of feed intake in herbage-fed ruminants. Proceedings of the Nutrition Society of Australia 10, 55-62. 